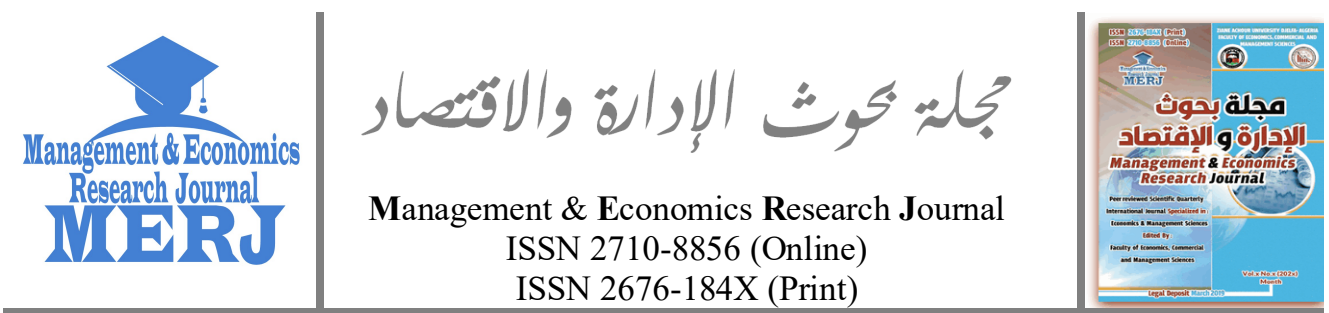

Management \& Economics Research Journal, Vol. 2 No.4 (2020), pp. 45-65

do) https://doi.org/10.48100/merj.v2i4.124

\title{
The Short and Long Run Determinants of Foreign Direct Investment in Nigeria
}

\author{
Oludayo Elijah Adekunle ${ }^{1}$ - \\ ${ }^{1}$ Adekunle Ajasin University Akungba-Akoko, Ondo State (Nigeria) \\ $\triangle$ adekunleoludayo864@yahoo.com
}

Received: 15-06-2020

Accepted: 29-07-2020

Published: 22-09-2020

\begin{abstract}
:
What determines foreign direct investment inflows has been controversial among scholars. As a result of the highlighted gap discussed in this study, the short and long-run determinants of foreign direct investment and their effects on foreign direct investment inflow in Nigeria were investigated from 1986 to 2018. Data were analyzed with Augmented Dickey-Fuller and Phillips Perron unit root test, Autoregressive Distributed Lag, and Pairwise Granger Causality techniques. Evidence of a long-run dynamic equilibrium relationship was established between foreign direct investment and its determinants. The short and long-run coefficients revealed that government capital expenditure and inflation impede the inflow of foreign direct investment both in the short and long run. At the same time, exchange rates are a bane to foreign direct investment in the long run. However, gross domestic product and trade openness was found to stimulate the inflow of foreign direct investment in the short and long run. The Pairwise causality result revealed that government capital expenditure, exchange rate, and trade openness had independent causality with foreign direct investment. In contrast, gross domestic product and inflation rate had unidirectional causality with foreign direct investment. Thus, the government should allocate more funds to enabling and enhancing the environment to promote foreign direct investment inflow. The study added value to previous studies by estimating the short and long-run determinants of foreign direct investment using the more dynamic and robust technique of
\end{abstract}

- Corresponding author: Adekunle Ajasin University Akungba-Akoko, Ondo State (Nigeria). [ $\$ adekunleoludayo864@yahoo.com] 
Autoregressive Distributed Lag developed by Pesaran and Shin (1999). Keywords: ARDL, Causality, Economic Policies, Foreign Direct Investment.

JEL Codes: C32, F21.

\section{Introduction}

Foreign direct investment plays a significant role in the development of most economies. The wave of globalization has led many countries to open their economy to the inflow of international investments through liberalization policy (Ramirez, 2006; Akinwale, Adekunle \& Obagunwa, 2018). The need for foreign direct investment arises due to the inability of most developing countries to adequately harness their resources in achieving aspired growth and development needed. The foreign direct investment serves as one of the significant development tools for most emerging and transition nations due to the diverse opportunities it offers to the host countries. Iffiong and Atsu (2014); Koko, Aminurraasyid, and Tapiwa (2017) opined that it is a source of infrastructure, employment generation, resource utilization, and access to international markets as well as managerial and technological transfers.

Theoretically, the foreign direct investment provides cross-border financing opportunities to local firms, promotes access to the foreign market, boosts international trade integration, aids human capital development, provides risk and product diversification opportunities, stimulates efficiency and effectiveness among local industries, and increases productivity (Li \& Liu, 2005; Lee, Lvendis \& Guitierrez, 2012; Yao, 2006; Ramirez, 2006; Ebiringa \& Emeh, 2013; Garavito, Iregui \& Ramirez 2014; Ojong, Felix \& Anthony, 2015). As a result of the crucial role played by foreign direct investment in promoting sustainable growth and development, countries of the world, incredibly less developed and transition economies like Malaysia, Ghana, South Africa, and Nigeria, among others, adopted liberalized their economy in the early 80's inline World Bank and International Monetary Fund policy proposal to boost international relationships and encourage the inflow of foreign direct investment. Dunning (2009), Vasconcellos and Kish (1998), and Enisan (2017) asserted that the different macroeconomic policies and reforms in most countries are directed toward encouraging the inflow of foreign direct investment.

However, the extent of the inflow of foreign direct investment in an economy is determined by certain factors peculiar to the host country. Mfinanga (2018) stated that the inflow of foreign direct investment in the host country is based on long-term commitment because it involves large 
investment capital, which is very difficult to recover if there is cyclical fluctuation, uncertainties, and economic instability in the host country. Thus, foreign investors' investment decision in the host country partly relies on the host country'scountry's prevailing economic conditions and investment environment (Wheeler \& Mody, 1992; Suleiman, Kaliappan \& Ismail, 2015). Narayan (2014) opined that determinants of foreign investment in a host country include factors such as market size, rate of urbanization and industrialization, labour cost, infrastructure both physical, inflation, tax regime, external debt are economical, country policy frameworks such as trade policies, country risk, legal framework including property rights, quality of bureaucracy and the attitude of the government towards foreign direct investment.

Over the years, the major policy thrust of government in Nigeria has been anchored upon the attraction of foreign direct investment inflow in the country. After adopting the liberalization policy in 1986, through which the economy was deregulated and opened to the inflow of foreign investment, Nigeria has witnessed significant growth in foreign direct investment. Ojong et al. (2015) stated that adopting policies like SAP in 1986, the industrial policy of 1989, the Export Processing Zone Decree of 1991, Nigerian Investment Promotion Commission (NIPC) through decree 16 of 1995 were aimed at enhancing the inflow of foreign direct investment into the country.

Dinda (2009) in Oba and Onuoha (2013) opined that Nigeria is the primary recipient of foreign direct investment among African nations receiving $70 \%$ of the sub-regional total and $11 \%$ of Africa'sAfrica's total, and out of this; Nigeria's oil sector alone received 90\% between 1970 and 2006. Recently, there has been a significant fluctuation in the inflow of foreign direct investment into Nigeria. Foreign direct investment inflow fell from N875.1 billion in 2013 to N738.2 billion in 2014. Furthermore, the country experienced a decline in foreign direct investment in 2015, with foreign direct investment stock falling to N602.1 billion. However, there was an increase in the inflow of foreign direct investment in 2016 to N1,124.1 billion before reducing to N1,069.4 and N610.4 billion in 2017 and 2018, respectively (CBN, 2018). Ojong et al. (2015) averred that foreign investors are unwilling to invest in Nigeria due to the perceived riskiness of doing business there. The Nigerian investment environment is characterized by high inflation, poor infrastructure, unstable exchange rate, political instability, financial crisis, recession and the recent Corona Virus Disease (COVID-19) outbreak.

There are various studies on the determinants of foreign direct investment inflows in both developed and developing nations (Korez-Vide, 
Voller \& Bobel, 2014; Portilla, Maza, Villaverde \& Hierro, 2016; Suleiman et al., 2015; Narayan, 2014; Eshghi, Eshghi \& Li, 2016; Ibrahim, Omar \& Ali, 2017). In Nigeria, most studies primarily focused on foreign direct investment's effect on economic growth. Few studies on the determinants of foreign direct investment in Nigeria were based on the long run by employing Ordinary Least Square techniques (Oba \& Onuoha, 2013; Etim et al., 2014; Ojong et al., 2015; Koko et al., 2017). Most of the studies established mixed results. However, the studies did not focus on the longrun and short-run determinants of foreign direct investment using the Autoregressive Distributed Lag approach.

Also, while determinants variables such as trade openness, political stability, market size and inflation rate were adopted by some studies, essential determinants such as government capital expenditure and exchange rate were not captured. According to Dunning's theory of foreign direct investment determinants, government capital expenditure plays a significant role in the economy by providing a conducive and enabling environment. At the same time, the exchange rate determines the purchasing power of local currency to foreign currencies and the stability of the external economy of the host country. In the same vein, the direction of causality between determinants of foreign direct investment and the foreign direct inflow was not established. Finally, this study advances previous studies by extending the study period to 2018, as most of the studies stopped at different periods, the latest being 2016 (Etim et al., 2014; Ojong et al., 2015; Koko et al., 2017; Ebire, Onmonya \& Ini, 2018). In recent times, Nigeria has experienced different economic situations, such as high insecurity, political instability, recession, exchange rate fluctuation, and financial sector turmoil, among others. Thus, there is a need to re-investigate the determinants of foreign direct investment in the economy, given the high unemployment rate, low standard of living and poverty in the economy. Thus, the study sought to achieve the following objectives:

- investigate the effect of government capital expenditure on foreign direct investment;

- examine the effect of gross domestic product (market size) on foreign direct investment;

- establish the effect of exchange rate on foreign direct investment;

- determine the effect of the inflation rate on foreign direct investment;

- examine the effect of trade openness on foreign direct investment;

- establish the directionality of causality between the determinants of foreign direct investment and foreign direct investment inflow in 


\section{Nigeria.}

Other than the current introductory part, the paper was sectionalized into the literature review, methodology, discussion of findings and conclusion.

\section{Literature review}

The role of foreign direct investment in the economy has been well documented in the literature (Dunning, 2009; Suleiman et al., 2015; Narayan, 2014; Eshghi et al., 2016; Ibrahim et al., 2017). Foreign direct investment is a form of investment undertaken by foreign citizens to create physical assets and production capacity in a host country. It is the ownership or control of entire or some fractional part of firms by foreigners in a domestic economy through the acquisition or creation of new assets, purchase of existing assets or joint ownership with the government or citizens of the host countries (Oba \& Onuoha, 2013).

Foreign direct investment serves as a driver of growth and development by providing investment capital, boosting competition and aiding local firms in adapting more efficient technology and management styles. Portilla et al. (2016); Mfinanga (2018) state that foreign direct investment reduces poverty, sustains economic growth and stimulates the smooth and favourable integration of the country's economy into the global international economy, which promotes long-run development. Due to the insufficiency of domestic investment to promote the growth aspiration of an economy, the need for international investment to stimulate growth becomes necessary. However, the capacity of an economy to attract the inflow of foreign investment depends on some factors.

Theatrically, the eclectic paradigm theory' assigned to Dunning $(1977$; 1993) provides a framework for the determinants of foreign direct investment, which are a set of advantages such as Ownership advantage, Internalisation advantage, and Location advantage. The advantages hover around factors such as high per capita income, large market size and growth, cheap labour, raw materials, and natural resources, low tariffs, easy macroeconomic policies, tax holidays, financial stability and low transaction costs, which must be present in host countries.

Studies conducted in developed countries stressed the role of some factors in enhancing the inflow of foreign direct investment. Garavito et al. (2014) employed large firm-level data set to investigate the determinants of foreign direct investment (FDI) in Colombia, which was analysed through Panel Probit. It was revealed that firms listed on the stock market, involved in foreign trade activities, and operating in sectors with greater capital 
intensity are more likely to be recipients of FDI. Korez-Vide et al. (2014) explored foreign direct investment location choice factors of German and Austrian companies in Brazilian regions. The study employed Multinomial Nested Logit Model and supplemented its findings with the qualitative analysis based on semi-structured expert interviews. The analyses showed that investor-nation-specific agglomeration, industry specialisation, workforce qualification and physical infrastructure were important FDI location choice factors for German and Austrian companies in Brazil.

Portilla et al. (2016) analysed the determinants of the inflow of foreign direct investment (FDI) in Spain at regional and sectoral levels between 1997 and 2013. The study applied GMM and GLS. It was found that FDI inflows in Spain are mainly determined by market size, the level of human capital in interaction with wages, and the own characteristics of Madrid. In the recent study by Klimeck (2018), negative binomial regression was employed to evaluate the role of agglomeration economies in FDI in ABS in Poland. The selected variables include GDP, GDP per capita, Density of ABS, Density of firms, Students, Technical students, Economics students, Capital city, Internal migration density and External migration density. The results of the analysis revealed that agglomeration economies had a significant effect on FDI in the service industry. All the variables relating to agglomeration were established to positively and significantly affect FDI. O'Meara (2015) examined the determinants of foreign direct investment cross-country by using a large sample of both developed and developing countries, which were analysed using pooled regression technique. It was found that the country's size and scale of economic activity in the host country significantly affected foreign direct investment flows. In contrast, economic freedom, tax incentives and human capital were insignificant in determining foreign direct investment.

Also, in developing countries, it was found that determinants of foreign direct investment are germane in promoting the inflow of foreign direct investment. Narayan (2014) analysed the determinants of FDI inflows in India from 2012 to 2013 by employing a correlation matrix and multiple regression techniques to analyse the relationship between FDI determinants and FDI inflows was analysed. It was found that the size of GDP and GDP growth rate are important for attracting higher inflows of FDI and higher FOREX reserves served as major determinants of FDI in India. Eshghi et al. (2016) investigated the impact of the corporate tax rate on foreign direct investment inflows from Germany into five Central and Eastern European countries from 2000 to 2012. The study employed a simple least-square analysis. It was found that the corporate tax rate significantly and negatively 
impacted FDI inflows in Central and Eastern European countries.

Suleiman et al. (2015) examined the determinants of Foreign Direct Investment (FDI) in Southern Africa Customs Union (SACU) countries by employing panel data from the period 1990-2010, which was analysed using Pooled OLS as the primary estimation method. The findings revealed that market size, natural resource availability and trade openness are positive and significant determinants of FDI for the SACU member countries. Mfinanga (2018) assessed the determinants of foreign direct investment inflow in Tanzania by employing annual time series data from World Bank Development indicators which covered the period between 1990 and 2015 which was analysed using Ordinary Least Square (OLS) and Augmented Dickey-Fuller. Market size, trade openness, inflation rate and exchange rate are selected sample variables in this study. The results found that the exchange rate is a major determinant of foreign direct investment inflow into Tanzania, indicating that the fluctuating exchange rate policy adopted by the country increases the inflow of foreign direct investment. Ibrahim et al. (2017) assessed Somalia's foreign direct investment (FDI) determinants. The study employed time-series data obtained from the World Bank and SESRIC for 41 years, that is, 1970-2010 and analysed using the Augmented Dickey-Fuller test used for the unit root test and ordinary least square statistical technique. The analysis showed a negative and significant relationship between exchange rate and FDI, while a positive and significant relationship was established between inflation, external debt and domestic investment of FDI. Finally, a negative and insignificant relationship was observed between the lack of government and FDI.

In Nigeria, Oba and Onuoha (2013) examined the relationship between determinants of foreign direct investment and economic growth by employing data that covered a period of ten years $(2001-2010)$ by variables such as real GDP, inflationary levels, the openness of trade, electricity consumption, transport and communication. The study employed regression analysis and revealed that real GDP, inflation and electricity consumption had a negative effect on foreign direct investment. In contrast, trade openness and transport and communication positively affected foreign direct investment. Offiong and Atsu (2014) investigated the determinants of foreign direct investment in Nigeria from 1980 to 2011 by assessing the relationships between GDP, wage rate, interest rate and relative openness index and foreign direct investment in Nigeria, which was analysed using multiple regression analysis. It was found that gross domestic and wage rates had a positive and significant effect on foreign direct investment. In contrast, trade openness and lending rate had an insignificant effect on 
foreign direct investment.

Etim et al. (2014) focus on the determinants of foreign direct investment and their impact in Nigeria from 1975 between 2010 Ordinary Least Square (OLS) and co-integration Error Correction Method (ECM) were employed and indicated that Market Size (GDP), openness, and the exchange rate had a significant impact on FDI inflow while political risk had an unfavourable effect on FDI inflow. Ojong et al. (2015) examined the factors that determine FDI inflow in Nigeria with the specific objectives of assessing the extent to which market capitalisation, trade openness, gross fixed capital formation and level of economic activities affect foreign direct investment inflow in Nigeria. Time-series data were collected from the CBN statistical Bulletin and were analysed using the ordinary least square multiple regression statistical technique, $\mathrm{ADF}$ and $\mathrm{PP}$ unit root. $\mathrm{A}$ correlation matrix was also used to check the relationship between all the variables and indicated that all the variables were strongly related except market capitalisation, gross fixed capital formation and level of economic activities, which had weak relation with FDI. The OLS result revealed an inverse relationship between market capitalisation and gross fixed capital formation on FDI inflow in Nigeria. At the same time, a highly liberal trade policy discourages foreign direct investment in Nigeria. Finally, there is a significant and positive effect of economic growth on FDI attraction in Nigeria.

In their Koko, Aminurraasyid and Tapiwa (2017) investigated the effect of political risk on FDI inflow to Nigeria using secondary data from 2000 to 2014, which was analysed using simple linear regression. Empirical results found that political risk had a positive and significant association with FDI in Nigeria. Nwosa and Adeleke (2017) examined the determinants of Foreign Direct Investment (FDI), and Foreign Portfolio Investment (FPI) volatility in Nigeria using annual data covering the periods 1986 to 2016 and analysed using the E-GARCH approach. The study observed that trade openness and world GDP were the significant determinants of FDI volatility. At the same time, domestic interest rates and stock market capitalisation were significant determinants of FPI volatility in Nigeria. Ebire et al. (2018) investigated the major determinants of FDI in Nigeria. The result showed that the major determinants of FDI inflows to Nigeria are the result of the exchange rate, GDP, first lag of GDP, military expenditure, and first lag of military expenditure, political stability, and financial development.

In summary, this study investigated the short and long-run determinants of foreign direct investment in Nigeria using a dynamic and 
robust technique of the Autoregressive Distributed Lag approach developed by Pesaran and Shin (1991), Pesaran and Smith (2001), which is a major advancement to previous studies. Also, the study contributed to the previous empirical literature by evaluating the direction of causality between foreign direct investment and its determinants. Finally, the study used more recent data, which gave room for recent findings regarding Nigeria's economy.

\section{Methodology}

This section presented the research procedures used in the study. It commenced with the research design and types and sources of data collection. The following procedure is the model specification based on Dunning's $(1977 ; 993)$ eclectic paradigm theory. The a priori expectation was formulated in line with this theory. Finally, the last procedure is the method of analyzing data.

\subsection{Research design and data collection}

This study was based on a quantitative research methodology to investigate the effect of foreign direct investment determinants on the inflow of foreign direct investment in Nigeria. This is because the data employed were numerical and historical data subject to econometric analysis for inferences and conclusions. The data for the study were time series and covered the period of 1986 to 2018. Data on foreign direct investment, government capital expenditure, gross domestic product, exchange rate, inflation rate and trade openness were obtained from the Central Bank of Nigerian Statistical Bulletin (2018).

\subsection{Model specification}

This study was pinned on the eclectic paradigm theory developed by Dunning (1977; 1993). This theory stresses the role of determinants factors such as per capita income, large market size, market growth, easy macroeconomic policies, tax holiday, financial stability and low transaction costs, which must be present in host countries. This theory opined that for foreign investors to invest in the host economy, there must be a specific advantage that must be prevalent in the host economy. Such advantage includes stable and easy macroeconomic policies and a suitable investment environment (Soderstern, 2006; Dunning, 2009).

However, the model for the study followed the model of Etim et al. (2014), Ojong et al. (2015), and Koko et al. (2017) with little modification to include essential variables like government capital expenditure and exchange rate. Thus, the model for the study is given as follows: 
$\mathrm{FDI}=(\mathrm{GCE}, \mathrm{GDP}, \mathrm{EXR}, \mathrm{INFR}, \mathrm{TOP})$

This is given econometric terms to include coefficients and error terms as:

$\mathrm{LFDI}=\beta_{0}+\beta_{1} \mathrm{LGCE}+\beta_{2} \mathrm{LGDP}+\beta_{3} \mathrm{EXR}+\beta_{4} \mathrm{INFR}+\beta_{5} \mathrm{TOP}+\mathrm{e}$

Where:

FDI $=$ Foreign Direct Investment. This measured the volume of foreign direct investment attracted by Nigeria's economy in billion and naira.

GCE = Government Capital Expenditure. This is the total government consumption representing expenditure in providing infrastructural facilities and enabling an environment for investors.

GDP $=$ Gross Domestic Product. This measured the size of Nigeria's economy in terms of the annual monetary value of goods and services.

$\mathrm{EXR}=$ Exchange Rate. This measured the value of the naira in foreign currencies. It captures the level of external balance of the economy.

INFR $=$ Inflation Rate. This measured the purchasing power of the naira and internal stability.

TOP $=$ Trade Openness (Summation of total exports and imports as a percentage of GDP). This captured the trade capacity of the economy and the level of openness of Nigeria to foreign relationships. It measures the level of openness to the inflow of capital and technology

$\mathrm{L}=$ Logarithm form of the Variables.

$\beta_{0}=$ Constant Term.

$\beta_{1}-\beta_{5}=$ Coefficient.

$\mathrm{e}=$ Stochastic Error Term.

A Priori Expectation.

Theoretically, it is expected that the determinants of foreign direct investment inflow will have a positive and significant effect on foreign direct investment. Thus, $\beta_{1}, \beta_{2}, \beta_{3}$ and $\beta_{5}>0$ while $\beta_{4}<0$. The larger the government capital expenditure, market size measured as a gross domestic product, stable exchange rate and openness of the economy, the higher the inflow of foreign direct investment, while unstable macroeconomic conditions through high inflationary pressure will lead to a fall in foreign direct investment inflow (Dunning, 1993; Wheeler \& Mody, 1992; Soderstern, 2006; Narayan, 2014, Suleiman, et al., 2015). 


\subsection{Method of data analysis}

This study adopted different econometric techniques to investigate the short and long-run effects of government capital expenditure, gross domestic product, exchange rate, inflation rate and trade openness on foreign direct investment in Nigeria. The Augmented Dickey-Fuller and Phillips Perron unit root techniques were employed to test the stationarity properties of the data series and obtain the order of integration of the variables. This is necessary to avoid the problem of spurious regression. The data series were found to be stationarity at the level and integrated at first difference 1(1), which justified the estimation of short and long-run dynamic regression Autoregressive Distributed Lag (ARDL) approach developed by Pesaran and Shin (1999) and Pesaran Shin and Smith (2001). This technique was suitable for the study because it is fitted for small sample sizes or data and corrects the problem of residual serial correlation and endogeneity by including sufficient lags in the model.

Furthermore, the study employed ARDL Bound Test to determine the existence of a long-run equilibrium between determinants of foreign direct investment, namely government capital expenditure, gross domestic product, exchange rate, inflation rate and trade openness and foreign direct investment. The equation for estimating the ARDL Bound Test is:

$\mathrm{D}\left(\mathrm{LFDI}_{\mathrm{t}}\right)=\alpha_{01}+\beta_{1} \mathrm{LFDI}_{\mathrm{t}-1}+\beta_{2} \mathrm{LGCE}_{\mathrm{t}-1}+\beta_{3} \mathrm{LGDP}_{\mathrm{t}-1}+\beta_{4} \mathrm{LEXR}_{\mathrm{t}-1}+\beta_{5} \mathrm{INFR}_{\mathrm{t}-1}+\beta_{6} \mathrm{TOP}_{\mathrm{t}-}$ ${ }_{1}+\sum_{\mathrm{i}=1}^{\mathrm{p}} \alpha 1 \mathrm{LFDI}_{\mathrm{t}-1}+\sum_{\mathrm{i}=1}^{\mathrm{p}} \alpha 2 \mathrm{LGCE}_{\mathrm{t}-1}+\sum_{\mathrm{i}=1}^{\mathrm{p}} \alpha 3 \mathrm{LGDP}_{\mathrm{t}-1}+\sum_{\mathrm{i}=1}^{\mathrm{p}} \alpha 4 \mathrm{LEXR}_{\mathrm{t}-1}+\sum_{\mathrm{i}=1}^{\mathrm{p}} \alpha 5$ INFR $_{\mathrm{t}-1}+$ $\sum_{\mathrm{i}=1}^{\mathrm{p}} \alpha 6 \mathrm{TOP}_{\mathrm{t}-1}+\varepsilon_{1}$

Where:

LFDI, LGCE, LGDP, LEXR, INFR, and TOP are variables of the study, $\mathrm{D}$ is the first difference, and $\varepsilon$ is the error term. The null hypothesis of no co-integration was tested against the alternate hypothesis of cointegration by comparing the F-test value against the lower bound critical value at $5 \%$.

Following the estimation of the ARDL Bound Test, the short and long-run dynamic coefficients were estimated with the following equations: by adopting the ECM-ARDL short-run approach, which is given as:

$$
\begin{aligned}
& L F D I_{t}=\alpha_{0}+\sum_{i=1}^{p} \lambda_{1} \Delta L F D I_{t-1}+\sum_{i=1}^{p} \lambda_{2} \Delta L G C E_{t-1}+\sum_{i=1}^{p} \lambda_{3} \Delta L G D P_{t-1}+ \\
& \sum_{i=1}^{p} \lambda_{4} \Delta L E X R_{t-1}+\sum_{i=1}^{p} \lambda_{5} \Delta I N F R_{t-1}+\sum_{i=1}^{p} \lambda_{6} \Delta T O P_{t-1}+\phi E C T_{t-1}+\mu_{T}
\end{aligned}
$$

$\lambda$ is the coefficients relating to the short-run dynamics of the 
convergence to equilibrium, $\Delta$ represents the differencing of the variables, $E C T_{t-1}$ is the error correction term resulting from the estimated long-run equilibrium relationship, and $\phi$ is the coefficient denoting the speed of adjustment to long-run equilibrium when there is a shock in the system, The long run coefficients of the ARDL model is thus given as:

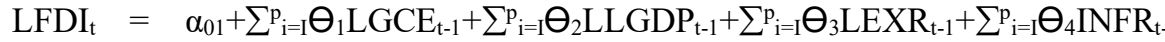

$$
\begin{aligned}
& { }_{1}+\sum_{\mathrm{i}=1}^{\mathrm{p}} \Theta_{5} \mathrm{TOP}_{\mathrm{t}-1}+\mathrm{e}_{\mathrm{t}}
\end{aligned}
$$

\section{Where:}

LFDI $=$ Log of Foreign Direct Investment, LGCE $=$ Log of Government Capital Expenditure, LGDP $=$ Log of Gross Domestic Product, LEXR $=$ Log of Exchange Rate, INFR $=$ Inflation Rate, TOP $=$ Trade Openness. $\theta_{1}-\theta_{5}$ represents the parameters of the variables. $\mathrm{e}=$ Error Term. Finally, the direction of causality among the variables was evaluated using the Pairwise Granger Causality technique.

\section{Result and discussion}

This section presents the results and interpretation of data analyzed using econometric techniques. It commenced with the presentation on unit root Augmented Dickey-Fuller and Phillips Perron unit root techniques presented in table 1 .

Table 1. Summary of augmented Dickey-Fuller and Phillips Perron results

\begin{tabular}{l|llll}
\hline Series & ADF t-statistics & Order of integration & $\begin{array}{l}\text { PP t- } \\
\text { statistics }\end{array}$ & $\begin{array}{l}\text { Order of } \\
\text { integration }\end{array}$ \\
\hline LFDI & -7.100035 & $\mathrm{I}(1)$ & -7.382755 & $\mathrm{I}(1)$ \\
LGCE & -6.171587 & $\mathrm{I}(1)$ & -6.119882 & $\mathrm{I}(1)$ \\
LGDP & -3.720387 & $\mathrm{I}(0)$ & -3.305926 & $\mathrm{I}(0)$ \\
LEXR & -5.655136 & $\mathrm{I}(1)$ & -3.023596 & $\mathrm{I}(0)$ \\
INFR & -4.746238 & $\mathrm{I}(1)$ & -5.672315 & $\mathrm{I}(1)$ \\
TOP & -3.221243 & $\mathrm{I}(0)$ & -3.165915 & $\mathrm{I}(0)$ \\
\hline
\end{tabular}

Source: Computed by the author from E-views 9.

The result of the Augmented Dickey-Fuller and Phillips Perron unit root test is presented in Table 1. The unit test was conducted to avoid the problem of non-genuine results and was tested at a 5\% significant level. Based on the Augmented Dickey-Fuller test, the log of gross domestic product and trade openness are stationary at a level. In contrast, the log of foreign direct investment, the log of government capital expenditure, the log of exchange rate and the inflation rate are stationarity at first difference. 
This indicates that the data series is a mixture of order zero and order one, which requires the estimation of short and long-run dynamic coefficients.

This is supported by the Phillips Perron result, which shows that the gross domestic product log, exchange rate and trade openness are stationary at a level. In contrast, the log of foreign direct investment, government capital expenditure and the inflation rate are integrated. Thus, the study estimated short and long-run dynamic coefficients using Autoregressive Distributed Lag Technique developed by Pesaran and Shin (1999). However, before estimating the short and long-run dynamic coefficients, it is necessary to ascertain the optimum lag, which was established using Akaike Information Criterion (AIC), criteria presented in Table 2.

Table 2. Optimum lag selection

\begin{tabular}{llll}
\hline Lag & AIC & SC & HQ \\
0 & 17.40408 & 17.68162 & 17.49455 \\
1 & 9.254682 & $11.19750 *$ & $9.887993^{*}$ \\
2 & $9.208756^{*}$ & 12.81685 & 10.38491 \\
$*$ indicates lag order selected by the criterion \\
AIC: Akaike information criterion \\
SC: Schwarz information criterion \\
HQ: Hannan-Quinn information criterion \\
\hline \multicolumn{5}{c}{ Source: Computed by the author from E-views 9.}
\end{tabular}

The result of the optimum lag is indicated in Table 2. Based on the result, the Akaike Information Criterion (AIC) shows that the suitable lag for estimating the short and long-run coefficients is 2 . Thus, the analysis evaluated the long-run relationship between foreign direct investment determinants, namely government capital expenditure, gross domestic product, exchange rate, inflation rate and trade openness and foreign direct investment inflow using the ARDL Bound technique given in Table 3.

Table 3: ARDL bound Test

\begin{tabular}{lcc}
\hline \multicolumn{3}{c}{ Null Hypothesis: No long-run relationships exist } \\
Test Statistic & Value & $\mathrm{K}$ \\
F-statistic & 4.893825 & 5 \\
\multicolumn{3}{c}{ Critical Value Bounds } \\
Significance & I0 Bound & I1 Bound \\
$10 \%$ & 2.26 & 3.35 \\
$5 \%$ & 2.62 & 3.79 \\
$2.5 \%$ & 2.96 & 4.18 \\
$1 \%$ & 3.41 & 4.68 \\
\hline \multicolumn{3}{r}{ Source: Computed by the author from E-views 9}
\end{tabular}

The result of the long-run relationship is presented in Table 3 . The 
null hypothesis of no long-run relationship is tested against the alternate hypothesis of the existence of a long-run relationship at a 5\% lower bound (I0) critical value. Evidence from the result shown in Table 3 reveals that the ARDL F-statistic value of 4.893825 is greater than the lower bound (I0) critical value of 2.62 at $5 \%$, indicating the rejection of the null hypothesis of no long-run relationships. Thus, it is concluded that foreign direct investment determinants, namely government capital expenditure, gross domestic product, exchange rate, inflation rate and trade openness, have a long-run dynamic relationship with foreign direct investment inflow in Nigeria. Thus, the analysis advances to estimating the short and long-run coefficients presented in Tables 4 and 5.

Table 4. ARDL short-run coefficients

\begin{tabular}{llll}
\hline \multicolumn{2}{l}{ Dependent variable: } & Foreign direct investment \\
Variable & Coefficient & t-Statistic & Prob. \\
D(LGCE) & -0.900786 & -1.291446 & 0.2138 \\
D(LGCE(-1)) & 1.590741 & 2.433991 & 0.0263 \\
D(LGDP) & 3.961751 & 1.293859 & 0.2130 \\
D(LGDP(-1)) & 6.781465 & 2.745688 & 0.0138 \\
D(LEXR) & 0.818712 & 1.089866 & 0.2910 \\
D(INFR) & -0.028667 & -1.811007 & 0.0878 \\
D(INFR(-1)) & 0.049613 & 3.050427 & 0.0072 \\
D(TOP) & 1.557851 & 1.899950 & 0.0745 \\
CointEq(-1) & -0.641226 & -4.779926 & 0.0002 \\
\hline
\end{tabular}

Source: Computed by the author from E-views 9

The short-run co-integrating result is presented in Table 4. The result shows that the first-period lag of the log of government capital expenditure, first-period lag of the gross domestic product and first-period lag of inflation rate have a positive and significant effect on the log of foreign direct investment in the short run. Also, in the short run log of government capital expenditure and inflation have a negative and insignificant effect on foreign direct investment in the current period.

However, the log of gross domestic product, exchange rate and trade openness have a positive but insignificant effect on foreign direct investment in the current period in the short run. Finally, the short-run result shows that the co-integrating equation has the expected negative sign of 0.641226 , which is significant at $5 \%$. This indicates that foreign direct investment adjusted speedily to short-run changes in the dynamic equation. This implies that feedback in the short-run disequilibrium is corrected at a speed of $64 \%$ towards the equilibrium path in the long run. 
Table 5: ARDL long run coefficients

\begin{tabular}{llll}
\hline \multicolumn{2}{l}{ Dependent Variable: Foreign Direct Investment } & \\
Variable & Coefficient & t-Statistic & Prob. \\
LGCE & -3.584808 & -4.351429 & 0.0004 \\
LGDP & 3.028801 & 3.686868 & 0.0018 \\
LEXR & -1.072071 & -1.064921 & 0.3018 \\
INFR & -0.149184 & -3.055561 & 0.0072 \\
TOP & 2.429489 & 1.868864 & 0.0790 \\
C & 1.042588 & 0.295283 & 0.7714 \\
\hline
\end{tabular}

Source: Computed by the author from E-views 9

The result of the long-run coefficients is presented in Table 5. The result shows that the $\log$ of government capital expenditure has a negative and significant effect on the log of foreign direct investment, which implies that government spending in the provision of a conducive climate for investment is not enough to induce the inflow of foreign direct investment in Nigeria. This indicates the bottleneck in the infrastructural facilities, which has continued to impede the inflow of foreign direct investment. This result is not in line with the a priori expectation and the findings of Suleiman et al. (2015).

However, the result shows that the log of gross domestic product, which measures the size of the economy, has a positive and significant effect on the $\log$ of foreign direct investment in the long run, which conforms to the a priori expectation. This implies that the larger the size of the Nigerian economy in terms of productivity, which signifies more considerable demand, the bigger the inflow of foreign direct investment in Nigeria. This indicates larger labour productivity, an essential determinant of foreign direct investment. This finding does not correspond to the result of Ibrahim et al. (2017); Mfinanga (2018) but is in line with the empirical findings of Narayan (2014); Offiong and Atsu (2014).

Conversely, the long-run result shows that the log of the exchange rate has a negative and insignificant effect on the log of foreign direct investment, which points to unstable and high naira depreciation. This implies that a higher exchange rate will make the business cost high, discouraging the inflow of foreign direct investment. This result does not conform to the a priori expectation and findings of Mfinanga (2018) but is in tandem with the findings of Narayan (2014).

Also, the inflation rate is found to have a negative and insignificant effect on the $\log$ of foreign direct investment, which implies that high inflationary pressure, which is a measure of internal stability, will lead to falling in the inflow of foreign direct investment in the long run which is 
line with the theoretical expectation. The finding is not supported by the result of Ibrahim et al. (2017); Nwosa and Adeleke (2017); Mfinanga (2018) though it is in line with the empirical analysis of Oba and Onuoha (2013); Suleiman et al. (2015).

Finally, it is found that trade openness has a positive but insignificant effect on foreign direct investment, which indicates that the more the openness of the country to international relations, the higher the inflow of foreign direct investment, which is in line with the prior expectation and supported by the findings of Oba and Onuoha (2013); Offiong and Atsu (2014); Nwosa and Adeleke (2017) though not in tandem with findings of Mfinanga (2018).

Table 6: Diagnostic and stability test

\begin{tabular}{lll}
\hline Diagnostics test & Chi-square value & P-value \\
\hline Normality test & 2.6639 & 0.263968 \\
Breusch-Godfrey LM test for serial correlation & 0.2921 & 2.461413 \\
Heteroskedasticity test: Harvey & 0.6863 & 10.09358 \\
Ramsey RESET test of omitted variables & 0.2587 & 1.171117 \\
\hline
\end{tabular}

Source: Computed by the author from E-views 9

Table 6 shows the diagnostics and stability test for the regression result. The Jarque-Bera normality test reveals that the model's residual is usually distributed. Also, the Breusch-Godfrey Lagrange Multiplier test (LM) indicates that the regression model is not serially correlated. The result of the Harvey Heteroskedasticity test shows that the residual is Homoscedastic. Finally, the result revealed that the regression model is relatively stable.

Table 7. Pairwise Granger causality tests

\begin{tabular}{|c|c|c|c|}
\hline Null Hypothesis: & Obs & $\begin{array}{l}\text { F- } \\
\text { Statistic }\end{array}$ & Prob. \\
\hline LGCE does not Granger Cause LFDI & 31 & 0.24808 & 0.7821 \\
\hline LFDI does not Granger Cause LGCE & & 0.20066 & 0.8194 \\
\hline LGDP does not Granger Cause LFDI & 31 & 0.19978 & 0.8202 \\
\hline LFDI does not Granger Cause LGDP & & 3.99355 & 0.0307 \\
\hline LEXR does not Granger Cause LFDI & 31 & 0.12276 & 0.8850 \\
\hline LFDI does not Granger Cause LEXR & & 0.21600 & 0.8072 \\
\hline INFR does not Granger Cause LFDI & 31 & 1.70920 & 0.2007 \\
\hline LFDI does not Granger Cause INFR & & 4.31460 & 0.0241 \\
\hline TOP does not Granger Cause LFDI & 31 & 0.13270 & 0.8763 \\
\hline LFDI does not Granger Cause TOP & & 0.88325 & 0.4255 \\
\hline
\end{tabular}

Source: Computed by Author from E-views 9 
The result of the Pairwise Granger causality tests is presented in Table 7. The result shows that the log of government capital expenditure, exchange rate log and trade openness have independent causality with the $\log$ of foreign direct investment. However, it is found in the result presented in Table 7 that $\log$ of gross domestic product and inflation rate have unidirectional causality with the $\log$ of foreign direct investment, with causality mainly flowing from the log of foreign direct investment to the log of gross domestic product and inflation rate.

\section{Conclusion}

The inflow of foreign direct investment serves as a source of growth and development to most developing countries like Nigeria. In recent years, the government has continued to stress the importance of foreign direct investment as a tool for assuaging the economy from some challenges facing the economy. The government has continued to put in place mechanisms and policies to attract the inflow of foreign direct investment in Nigeria. Thus, this study investigated the determinants of foreign direct investment and how they influence the inflow of foreign direct investment both in the short and long run in Nigeria.

In summary, it was found that both government capital expenditure and inflation rate impede the inflow of foreign direct investment both in the short and long run. This is an indication of the poor infrastructural facilities and unstable macroeconomic environment being experienced by Nigeria. This is highly connected and depicted in the government's annual budget in the nation's provision and revamping of infrastructural capacity. Also, the nation's high inflationary pressure has continued to be a bane to the inflow of foreign direct investment. The exchange rate was also established to contribute negatively to the inflow of foreign direct in the long run compared to the short run. This emphasized the unstable nature of the Nigeria exchange rate, which makes the cost of importing materials and doing business in the country high. Finally, it was revealed that market size measured by gross domestic product and trade openness stimulate the inflow of foreign direct investment both in the short and long run. This indicates that the large market size, high demand, and high labour productivity reflected in the high gross domestic of the economy encourage the inflow of foreign direct investment.

It was thus recommended that government should, as a matter of urgency, allocate more funds for the provision of enabling and investment enhancing the environment to stimulate the inflow of foreign direct investment in Nigeria. There should be massive allocation and investment in 
infrastructural facilities like roads, electricity and port in the country, along with ensuring a stable macroeconomic environment and political stability to promote foreign investment in the short and long run. The government also should address the issue of insecurities and internal threats. Finally, the nation's trade policy should be improved to ensure the economy's openness to the international market, technology and capital to attract the inflow of foreign direct investment into the economy.

However, this study was limited by the lack of enough data, which impedes the adoption of essential variables like political risk and insecurity. Thus, it was suggested that further studies should be conducted by adopting political risk and insecurity as essential determinants of foreign direct investment. Also, studies should be conducted to investigate sectoral determinants of foreign direct investment in Nigeria and other developing countries.

\section{References}

Akinwale, S.O., Adekunle, E.O. \& Obagunwa, T.B. (2018). Foreign direct investment inflow and agricultural sector productivity in Nigeria. Journal of Economics and Finance, 9(4), 12-19.

Dinda, S. (2009). Factors affecting FDI in Nigeria: An Empirical Investigation. MPRA Paper 40172, University Library of Munich, Germany, revised 16 Jul 2012.

Dunning, J.H. (1977). Trade, location of economic activity and the MNE: A search for an eclectic approach. In B. Ohlin, P.-O. Hesselborn, \& P. M. Wijkman (Eds.), The International Allocation of Economic Activity (pp. 395-418). Palgrave Macmillan UK.

Dunning, J.H. (1993). Multinational enterprises and the global economy. Wokingham: Addison-Wesley.

Dunning, J.H. (2009). Location and the multinational enterprise: a neglected factor? Journal of International Business Studies, 40, 5-19.

Ebiringa, O. T. \& Emeh, Y. (2013). Determinants of foreign direct investment inflow: A focus on Nigeria. European Journal of Business Management, 5(24), 41-53.

Ebire, K., Onmonya, O.L. \& Inim, V.E. (2018). Effects of the determinants of foreign direct investment in Nigeria: Error correction mechanism. Journal of Global Economics, 6 (4), 1-8.

Enisan, A.A. (2017). Determinants of foreign direct investment in Nigeria: A Markov Regime-Switching approach. Review of Innovation and 
Competitiveness, 3(1), 21-48.

Eshghi, G., Eshghi, A. \& Li, R. (2016). Corporate income tax as a determinant of foreign direct investment in Central and Eastern Europe. European Journal of Business and Social Sciences, 4(11), 111-123.

Etim, S.N., Oyenbuchi, O. \& Udo, N.C. (2014). The determinants of foreign direct investment and their impacts on Nigerian economy (1975 2010). Journal of Integrative Humanism, 74-84.

Garavito, A., Iregui, A.A. \& Ramirez, M.T. (2014). An empirical examination of the determinants of foreign direct investment: A firm-level analysis for the Colombian Economy. Revista de Economía del Rosario, 17(1), 5-31.

Ibrahim, M.I., Omar, Z.M. \& Ali, A.Y.S. (2017). The determinants of foreign direct investment in Somalia. International Journal of Economics and Financial Issues, 7(3), 713-720.

Iffiong, A.I. \& Atsu, I.A. (2014). Determinants of foreign direct investment in Nigeria (1980 - 201a1). International Review of Management and Business Research, 3(3), 1538-1550.

Klimek, A. (2018). Agglomeration economies and foreign direct investment in advanced business services in Poland. International Journal of Management and Economics, 54(1), 69-79.

Koko, M.H., Aminurraasyid, Y. \& Tapiwa, Z.K. (2017). Political risk and foreign direct investment in Nigeria: New empirical evidence. Accounting, 3(2017), 171-180

Korez-Vide, R., Voller, P. \& Bobel, V. (2014). German and Austrian foreign direct investment in Brazilian Regions: Which are the location choice factors? Journal of Management and Strategy, 5(4), 68-81.

Lee, S. H., Levendis, J. \& Guitierrez, L. (2012). Telecommunication and economic growth: empirical analysis of sub-Saharan Africa. Applied Economics, 44 (4), 461-469.

Li, X. \& Liu, X. (2005). Foreign direct investment and economic growth: an increasingly endogenous relationship. World Development, 33 (3), 393-407.

Mfinanga, R.I. (2018). Determinants of foreign direct investment inflow in Tanzania. Global Journal of Human and Social Science, 18(1), 38- 


\section{6.}

Narayan, L. (2014). Determinants of foreign direct investment in India. International Journal of Research, 1(7), 815-823.

Nwosa, P.I. \& Adeleke, O. (2017). Determinants of foreign direct investment and foreign portfolio investment volatility: an e-GARCH approach. CBN Journal of Applied Statistics, 8(2), 47-57.

Oba, U.O., \& Onuoha, B.C. (2013). The determinants of foreign direct investments (FDIs) and the Nigerian economy. American International Journal of Contemporary Research, 3(11), 165-172.

Ojong, C.M., Felix, A.O. \& Anthony, O. (2015). Determinants of foreign direct investment inflow to Nigeria. Journal of Humanities and Social Science, 20(8), 34-43.

O'Meara, G. (2015). Examining the determinants of foreign direct investment. Undergraduate Economic Review, 11(1), 1-11.

Pesaran, M. \& Shin, Y. (1999). An autoregressive distributed lag modelling approach to co-integration analysis. In Strom, S. (Eds). Paper Presented at Econometrics and Economics Theory in the 20th Century: The Ragnar Frisch Centennial Symposium, Cambridge University Press, Cambridge.

Pesaran, M., Shin, Y. \& Smith, R. (2001). Bounds testing approaches to the analysis of level relationships. Journal of Applied Econometrics, 16(3), 289-326.

Portilla, G.P., Maza, A. \& Hierro, V.M. (2016). Foreign direct investment in the Spanish regions: What are the influencing factors? Journal of Regional Research, 35,67-82.

Ramirez, M.D. (2006). Economic and institutional determinants of foreign direct investment in Chile: A time series analysis, 1960-2001. Contemporary economic policy, 24, 459-471. https://doi.org/10.1093/cep/byj027

Soderstern (2006). International economic. London: Macmillan Press Ltd.

Suleiman, N.N., Kaliappan, S.R. \& Ismail, N.W. (2015). Determinants of foreign direct investment: Empirical evidence from Southern Africa Customs Union (SACU) Countries. International Journal of Economics and Management, 9(1), $1-24$.

Vasconcellos, G.M. \& Kish, R.J. (1998). Cross-border mergers and acquisitions: The European-US experience. Journal of Multinational 
Financial Management, 8(4), 431-450.

Wheeler, D. \& Mody, A. (1992). International investment location decisions: The case of U.S. firms, Journal of International Economics, 33(1-2), 57-76.

Yao, S. (2006). On economic growth, FDI and exports in China. Applied Economics, 38 (3), 339-351.

(C) 2020 the Author(s). This is an open access article distributed under the terms of Creative Commons Attribution-Non Commercial License (CC BY-NC 4.0) which permits use, distribution and reproduction in any medium, provided the original work is properly cited and is not used for commercial purposes.

\section{Recommended citation:}

Adekunle, O. E. (2020). The Short and Long Run Determinants of Foreign Direct Investment in Nigeria. Management \& Economics Research Journal, 2(4), 45-65. https://merj.com/merj/index.php/merj/article/view/124 